\title{
Analisis Hidrodinamika dan Transformasi Gelombang bagi Re-design Breakwater di Pelabuhan Klungkung Bali
}

\author{
ALIF FARHAN DARMAWAN, YESSI NIRWANA KURNIADI \\ Jurusan Teknik Sipil Institut Teknologi Nasional \\ Email: aliffarhand27@gmail.com
}

\begin{abstract}
ABSTRAK
Pelabuhan Gunaksa Klungkung, Bali memerlukan breakwateruntuk melidungi pelabuhan dari gelombang tinggi. Analisis saat ini menunjukan bahwa breakwater yang ada tidak dapat mereduksi tinggi gelombang yang terjadi. Tujuan dari penelitian ini adalah untuk membuktikan bahwa breakwater yang ada saat ini tidak dapat mereduksi tinggi gelombang yang terjadi dengan analisis hidrodinamika dan transformasi gelombang. Pemodelan hidrodinamika di Pelabuhan Gunaksa dilakukan dengan cara mensimulasi gelombang dan melakukan kalibrasi data pasang surut pemodelan dengan pengamatan. Hasil dari simulasi ini menunjukkan bahwa saat pasang purnama arus bergerak daribarat daya ke timur laut dengan elevasi muka air tertinggi 0,9 $\mathrm{m}$ dan tinggi gelombang sebesar 0,56-0,64 m. Pada kondisi pasang perbani arus bergerak dari timur laut ke barat daya dengan elevasi muka air terendah -1,02 m dan tinggi gelombang sebesar 0,48 - 0,56 m. Tinggi gelombang yang terjadi melebihi $0,5 \mathrm{~m}$, oleh sebab itu Pelabuhan Gunaksa membutuhkan re-design breakwater.
\end{abstract}

Kata kunci: pemodelan, hidrodinamika, transformasi gelombang

\begin{abstract}
Gunaksa Harbour Klungkung, Bali needs breakwater to protect the harbour from high waves. Former analysis shows that the existing breakwater cannot reduce the height waves. The purpose of this research is to proves that the existing breakwater cannot reduce the height waves by hydryodynamic conditions and wave transformation.. Hydrodynamic modeling of Gunaksa Harbour, simulating waves and calibrated against data from a substantial field. Modeling results indicated that atspring tide, the current waves from southwest to northeast with the highest water level 0,9 $\mathrm{m}$ with the wave height is 0,56-0,64 m, while at neap tide, the current waves from northeast to southwest with the lowest water level$1,02 \mathrm{~m}$ with the wave height is 0,48-0,56 $\mathrm{m}$. The wave height requirements for harbour is 0,5 m, however the wave height is higher than 0,5 $\mathrm{m}$, therefore Gunanksa Harbour could need re-design breakwater.
\end{abstract}

Keywords: modeling, hydrodynamic, wave transformation 


\section{PENDAHULUAN}

Kabupaten Klungkung merupakan salah satu dari sembilan kabupaten/kota di Propinsi Bali. Kabupaten Klungkung dibagi dalam tiga wilayah kecamatan di daratan Pulau Bali dan satu wilayah kecamatan di Kepulauan Nusa Penida. Pertumbuhan dan perkembangannya, Kecamatan Nusa Penida cukup tertinggal jauh dibandingkan dengan tiga kecamatan yang berada di Klungkung daratan. Kendala utamanya adalah masalah aksesibilitas. Pemerintah Kabupaten Klungkung membangun Pelabuhan Angkutan Sungai dan Penyeberangan (ASDP) yang memiliki rute dari Padang Bai sampai ke Lembar yang dimulai pada Oktober 2003 dan selesai pada bulan Juli 2006.

Pelabuhan ASDP Klungkung ini memiliki tinggi gelombang yang dominan terutama dari arah timur, tenggara, timur, yaitu 1,1-1,4 $\mathrm{m}$. Kriteria tinggi gelombang pada pelabuhan memiliki tinggi gelombang maksimum $0,5 \mathrm{~m}$. Tinggi gelombang dominan yang terjadi melebihi $0,5 \mathrm{~m}$ yang mengakibatkan kapal tidak dapat berlabuh dengan baik. Pelabuhan ASDP ini memerlukan breakwater untuk menjaga area sekitar pelabuhan dari gelombang.

Analisis diperlukan untuk mengetahui bahwa breakwateryang ada mampu melindungi pelabuhan dari gelombang. Penelitian dilakukan dengan analisis hidrodinamika dan transformasi gelombang.

\section{TINJAUAN PUSTAKA}

\subsection{Pemodelan Hidrodinamika 2DH}

\section{Flow Model FM}

MIKE 21 memiliki kemampuan untuk memodelkan fenomena-fenomena yang terkait dengan sungai, danau, teluk, pantai, dan laut. MIKE 21 Flow Model FM adalah satu sistem modeling berbasis pada satu pendekatan flexible mesh yang dikembangkan untuk aplikasi didalam oceanografi, rekayasa pantai, dan muara sungai. Flow Model FMtu sendiri terdiri atas beberapa modul, diantaranya Hydrodinamic Module. Hydrodinamic Module adalah model matematika untuk menghitung perilaku hidrodinamika air terhadap berbagai macam fungsi gaya. Persamaan 1, Persamaan 2, dan Persamaan 3 berikut menggambarkan aliran dan perbedaan muka air.

$$
\begin{aligned}
& \frac{\partial \zeta}{\partial t}+\frac{\partial p}{\partial x}+\frac{\partial q}{\partial y}=\frac{\partial d}{\partial t} \\
& \frac{\partial p}{\partial t}+\frac{\partial}{\partial x}\left(\frac{p^{2}}{h}\right)+\frac{\partial}{\partial y}\left(\frac{p q}{h}\right)+g h \frac{\partial \zeta}{\partial x}+\frac{g p \sqrt{p^{2}+q^{2}}}{C^{2} \cdot h^{2}}-\frac{1}{\rho_{w}}\left[\frac{\partial}{\partial x}\left(h \tau_{x x}\right)+\frac{\partial}{\partial y}\left(h \tau_{x y}\right)\right]-\Omega_{q}-f V V_{x}+ \\
& \frac{h}{\rho_{w}} \frac{\partial}{\partial x}\left(p_{a}\right)=0 \\
& \frac{\partial q}{\partial t}+\frac{\partial}{\partial y}\left(\frac{q^{2}}{h}\right)+\frac{\partial}{\partial x}\left(\frac{p q}{h}\right)+g h \frac{\partial \zeta}{\partial y}+\frac{g p \sqrt{p^{2}+q^{2}}}{C^{2} \cdot h^{2}}-\frac{1}{\rho_{w}}\left[\frac{\partial}{\partial y}\left(h \tau_{x x}\right)+\frac{\partial}{\partial x}\left(h \tau_{x y}\right)\right]-\Omega_{p}-f V V_{y}+ \\
& \frac{h}{\rho_{w}} \frac{\partial}{\partial x y}\left(p_{a}\right)=0 \\
& \zeta(x, y, t)=\text { elevasi permukaan }[\mathrm{m}] \text {, } \\
& p, q(x, y, t)=\text { flux density dalam arah } x \text { dan } y\left[\mathrm{~m}^{3} / \mathrm{s} / \mathrm{m}\right]=(\mathrm{uh}, \mathrm{vh}) ;(\mathrm{u}, \mathrm{v}) \\
& =\text { depth average velocity dalam arah } x \text { dan } y \text {, } \\
& C(x, y)=\text { tahanan Chezy }\left[\mathrm{m}^{1 / 2} / \mathrm{s}\right] \text {, }
\end{aligned}
$$




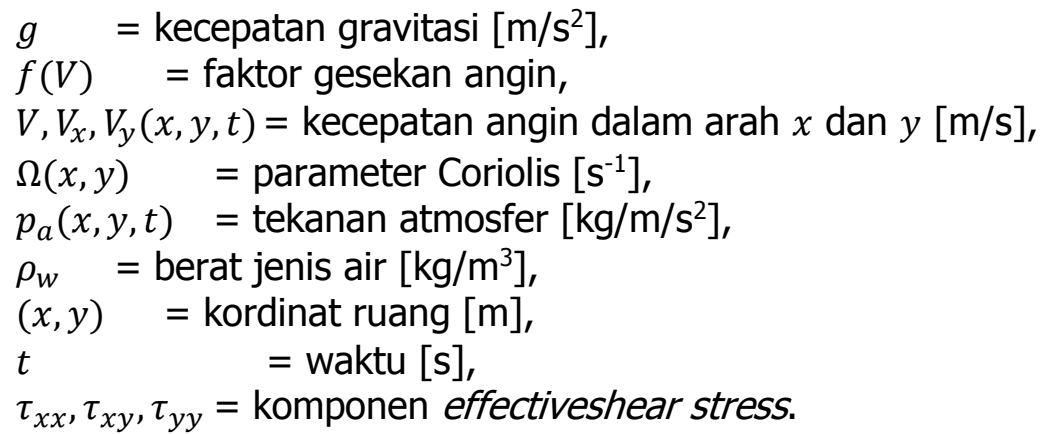

\section{Spectral Waves FM}

Prediksi gelombang dan analisis gelombang dalam skala regional dan skala lokal serta perhitungan transportasi sedimen yang sebagian besar ditentukan oleh kondisi gelombang dan wave-induced currents. Wave-incuded current disebabkan oleh gradient radiation stressed yang terjadi pada surf zone. Koordinat kartesius keseimbangan gaya gelombang dapat dilihat pada Persamaan 4 dan koordinat spherical gaya gelombang dapat dilihat pada Persamaan 5.

$$
\begin{aligned}
& \frac{\partial N}{\partial t}+\nabla \cdot(\vec{v} N)=\frac{S}{\sigma} \\
& \widehat{N}=N R^{2} \cos \emptyset=\frac{E R^{2} \cos \emptyset}{\sigma}
\end{aligned}
$$

dengan:

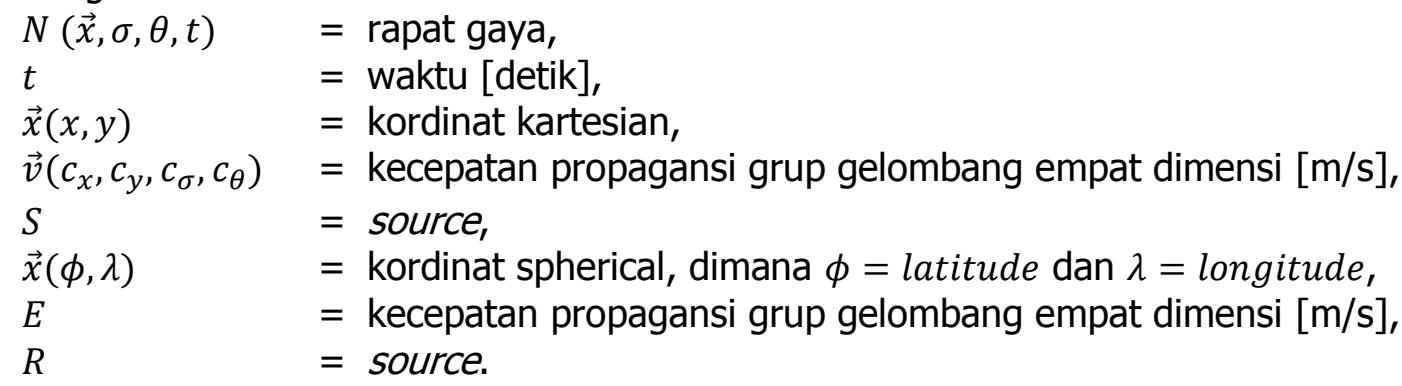

\subsection{Analisis Hidrodinamika dan Transformasi Gelombang}

Berdasarkan penelitian Fadli (2014) kondisi hidrodinamika dilihat pada dua kondisi, yaitu pada kondisi pasang purnama dan kondisi pasang perbani. Pada kondisi pasang purnama akan menghasilkan nilai pasang surut tertinggi, hal ini disebabkan karena posisi bulan, bumi, dan matahari yang segaris sehingga gaya tarik gravitasi dalam keadaan maksimum, sedangkan pada kondisi pasang perbani akan menghasilkan nilai pasang surut terendah, hal ini disebabkan karena posisi bumi, bulan, dan matahari yang membentuk sudut $90^{\circ}$ sehingga gaya tarik gravitasinya minimum. Pada pemodelan transformasi gelombang dapat dilihat elevasi muka air di mulut kolam pelabuhan.

\section{METODOLOGI PENELITIAN}

\subsection{Lokasi Penelitian}

Penelitian dilakukan pada kawasan pelabuhan Gunaksa Kabupaten Klungkungsecara geografis terletak di lintang $-8,573311^{\circ}$ dan bujur $115,433595^{\circ}$ (Gambar 1). 


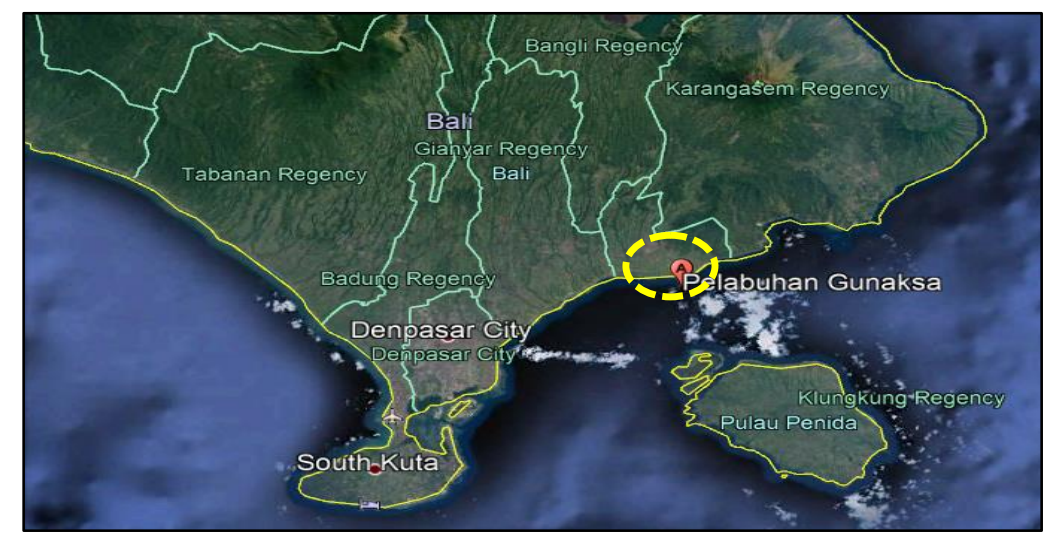

Gambar 1. Lokasi penelitian

(Sumber: Google Earth, 2018)

\subsection{Alur Penelitian}

Penelitian ini dilakukan untuk menentukan rumusan masalah yang terjadi pada breakwater di Pelabuhan Gunaksa. Data-data yang diperlukan dalam penelitian adalah data batimetri, data pasang surut, data angin, dan data gelombang. Data-data tersebut diperlukan dalam analisis hidrodinamika dan transformasi gelombang. Validasi data pasang surut dan pemodelannya mengikuti fase dan amplitudo pasang surut pengamatan. Pola hidrodinamika disajikan berupa elevasi muka air dan arah arus. Transformasi gelombang dimodelkan dengan bantuan software MIKE 21 modul Spectral Waves FM. Hasil dari pemodelan transformasi gelombang berupa arah arus dan tinggi gelombang.

\section{PENGOLAHAN DATA DAN PEMBAHASAN}

\subsection{Pengolahan Data Validasi}

Berikut ini merupakan hasil pengolahan data pasang surut (Gambar 2).

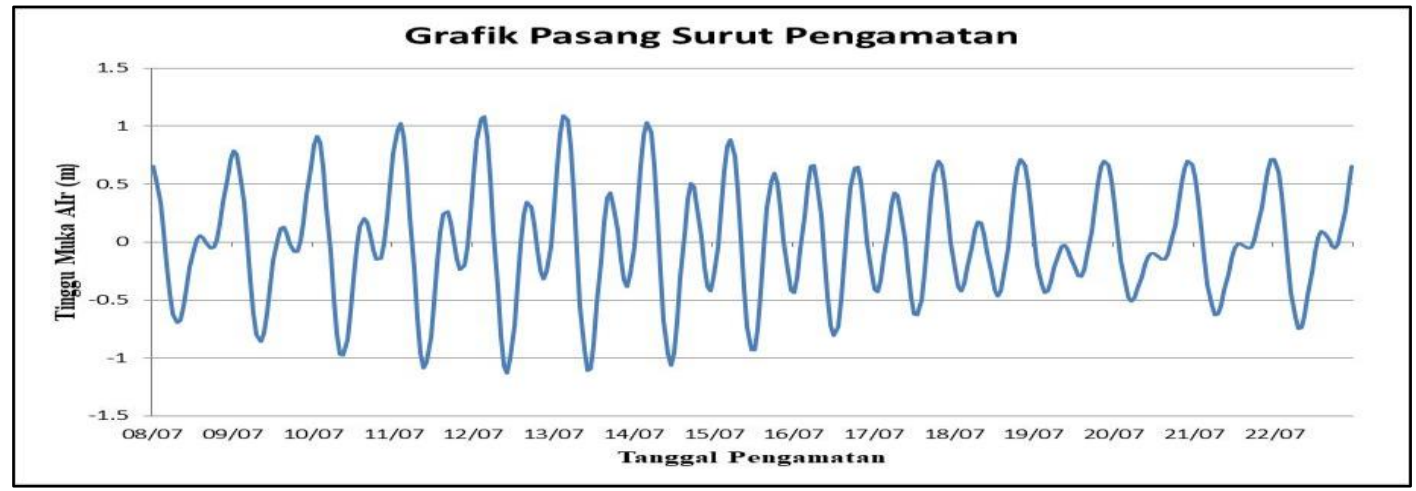

Gambar 2. Kurva pasang surut hasil pengamatan

Gambar 2 menunjukkan bahwa pada rentang 8 Juli hingga 22 Juli tinggi muka air terbesar $1,1 \mathrm{~m}$ terjadi pada tanggal 12 Juli dan 13 Juli, sedangkan tinggi muka air terendah-1,1 m terjadi pada tanggal 12 Juli dan 13 Juli.Jenis pasang surutnya termasuk jenis pasang surut campuran semi diurnal. Hal ini ditandai dengan terjadi satu kali pasang dan satu kali surut pada hari yang sama namun beberapa kalijuga terjadi dua kali pasang dan dua kali surut pada hari yang sama.

\subsection{Validasi Data}

Berikut ini merupakan parameter yang digunakan Tabel 1 dan validasi data pasang surut pengamatan dan pemodelan (Gambar 3). 
Tabel 1. Parameter yang Digunakan dalam Setup PemodelanHidrodinamika

\begin{tabular}{ll}
\multicolumn{1}{c}{ Parameter } & \multicolumn{1}{c}{ Diterapkan dalam Pemodelan } \\
Mesh and Bathymetry & Hasil interpolasi mesh \\
\hline Simulation Period & No. of time step $=360$ \\
& Time step interval $=3600 \mathrm{~s}$ \\
& Simulation start date $=7 / 8 / 2006$ \\
& Simulation end date $=7 / 22 / 2006$ \\
\hline Eddy Viscosity & Constant Value $=0,28$ \\
\hline Bed Resistance & Manning $=37 \mathrm{~m}^{1 / 3} / \mathrm{s}$ \\
\hline Boundary Condition & Hasil prediksi tiap boundary \\
\hline
\end{tabular}

\subsection{Simulasi Pemodelan}

Dalam pemodelandilakukan kalibrasi pemodelan agar mendapat hasil yang valid antara pengamatan dengan pemodelan. Percobaan pemodelan dengan berbagai nilai manning atau Bed Resistence menghasilkan rekapitulasi yang dapat dilihat pada Tabel $\mathbf{2}$.

Tabel 2. Rekapitulasi Hasil Kalibrasi

\begin{tabular}{ccc}
$\begin{array}{c}\text { Bed } \\
\text { Resistence }\end{array}$ & $\begin{array}{c}\text { Error } \\
\text { Method }\end{array}$ & $\begin{array}{c}\text { Elevasi } \\
\text { Muka Air }\end{array}$ \\
\hline 28 & RMSE & 0,2957 \\
\cline { 2 - 3 } & Korelasi(\%) & 81,4605 \\
\hline 30 & RMSE & 0,2982 \\
\cline { 2 - 3 } & Korelasi(\%) & 81,2799 \\
\hline 32 & RMSE & 0,2960 \\
\hline \multirow{2}{*}{35} & Korelasi(\%) & 81,4301 \\
\hline \multirow{2}{*}{37} & RMSE & 0,2967 \\
\cline { 2 - 3 } & Korelasi(\%) & 81,4632 \\
\cline { 2 - 3 } & RMSE & 0,2954 \\
\hline
\end{tabular}

Berdasarkan hasil tersebut dipilih nilai manning $=37 \mathrm{~m}^{1 / 3}$ karena memiliki nilai RMSE dan nilai korelasi yang cukup tinggi dibandingkan yang lainnya. Hasil kalibrasi dapat dilihat pada Gambar 3.

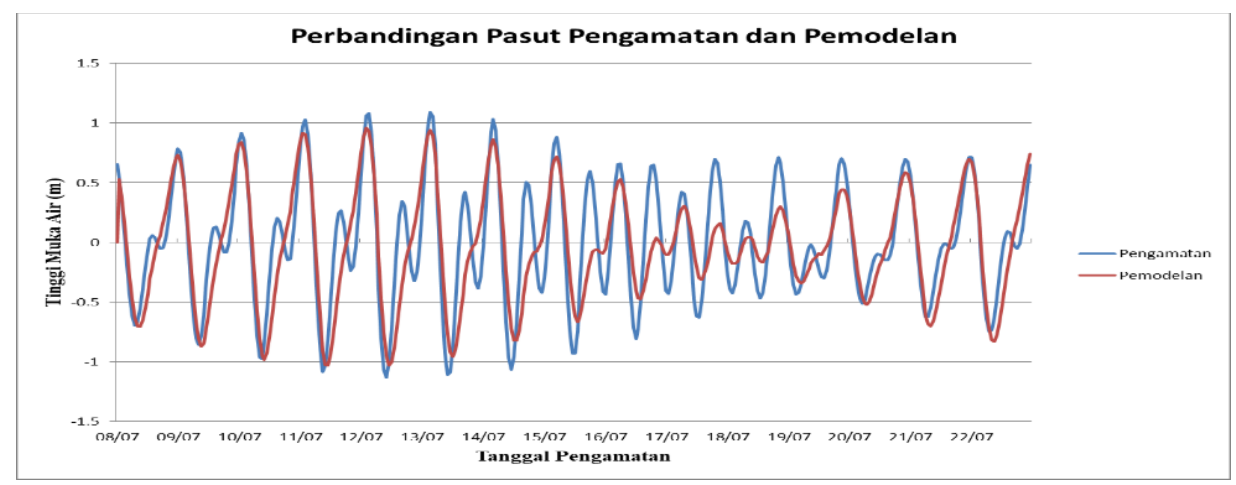

Gambar 3. Grafik perbandingan pasang surut pengamatan dan pemodelan

Gambar 3 menunjukan bahwa pasang surut pengamatan dan pemodelan hampir sama, namun pada beberapa bagian time step terdapat elevasi muka air yang berbeda.

RekaRacana: Jurnal Teknik Sipil - 99 


\subsection{Hasil Analisis Hidrodinamika}

Berikut ini adalah hasil dari simulasi hidrodinamika pada saat angin barat (Desember s.d Februari) dan angin timur (Juni s.d Agustus) dengan kondisi pasang purnama dan kondisi pasang perbani.

1. Kondisi pasang purnama pada saat angin barat (Desember s.d Februari)

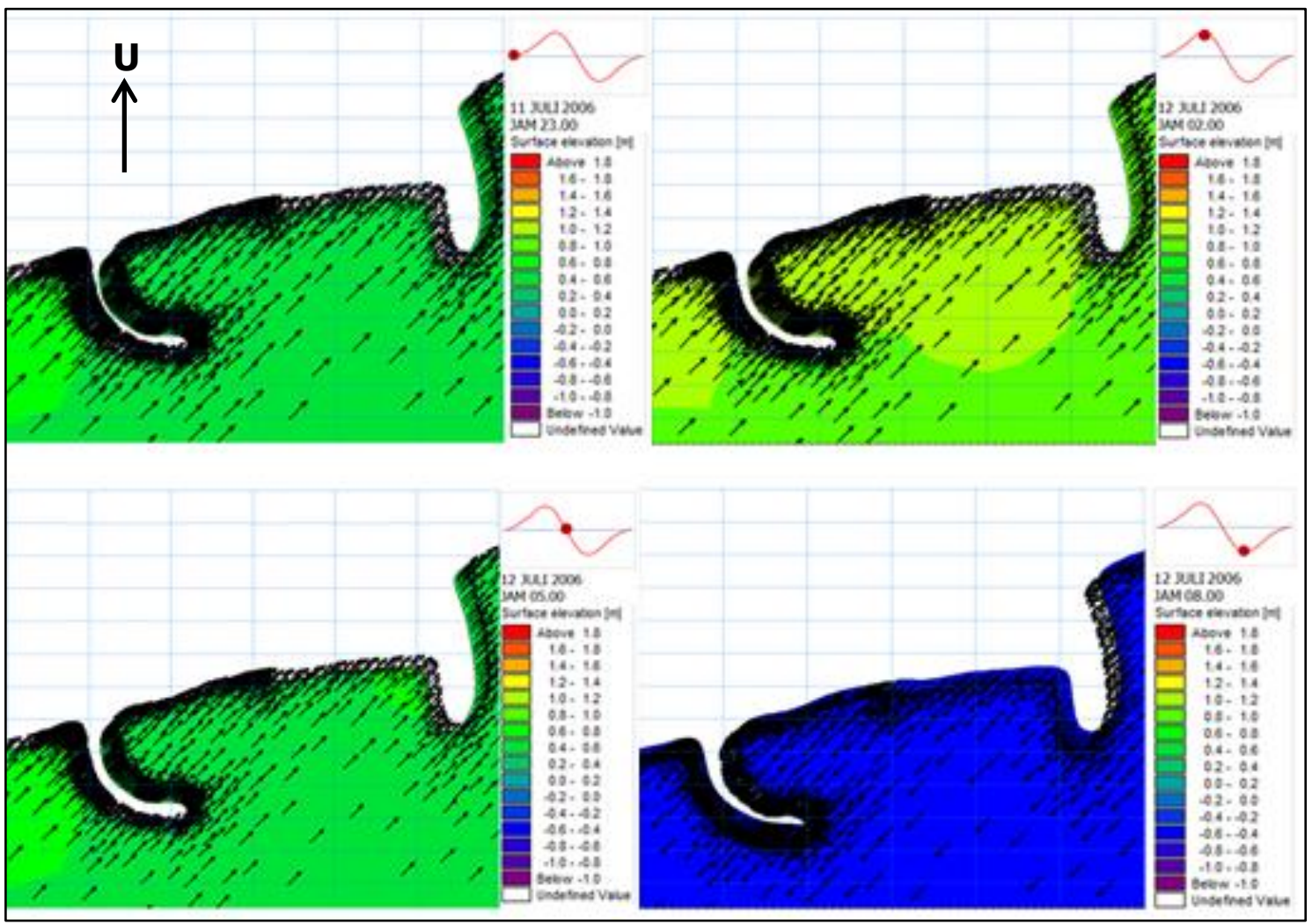

Gambar 4. Kondisi pasang purnama saat angin barat pada tanggal 12 Juli 2006

Gambar 4 menunjukan kondisi pasang purnama saat angin barat yang menunjukan beberapa kondisi yaitu padasaat surut menuju pasang yang terjadi pada tanggal 11 Juli 2006 pukul 23.00, pasang tertinggi yang terjadi pada tanggal 12 Juli 2006 pukul 02.00 , pasang menuju surut yang terjadi pada tanggal 12 Juli 2006 pukul 05.00, dan surut terendah yang terjadi pada tanggal 12 Juli 2006 pukul 08.00, arus di sekitar pelabuhan ASDP Klungkung Bali bergerak dari arah barat daya ke arah timur laut. Elevasi muka air pada saat surut menuju pasang sebesar 0,54 $\mathrm{m}$, pada saat pasang tertinggi sebesar 0,99 $\mathrm{m}$, pada saat pasang menuju surut sebesar 0,55 $\mathrm{m}$, dan pada saat surut terendah sebesar-0,46 m. 


\section{Analisis Hidrodinamika dan Transformasi Gelombang bagi Re-design Breakwater di Pelabuhan Klungkung Bali}

2. Kondisi pasang perbani pada saat angin barat (Desember s.d Februari)

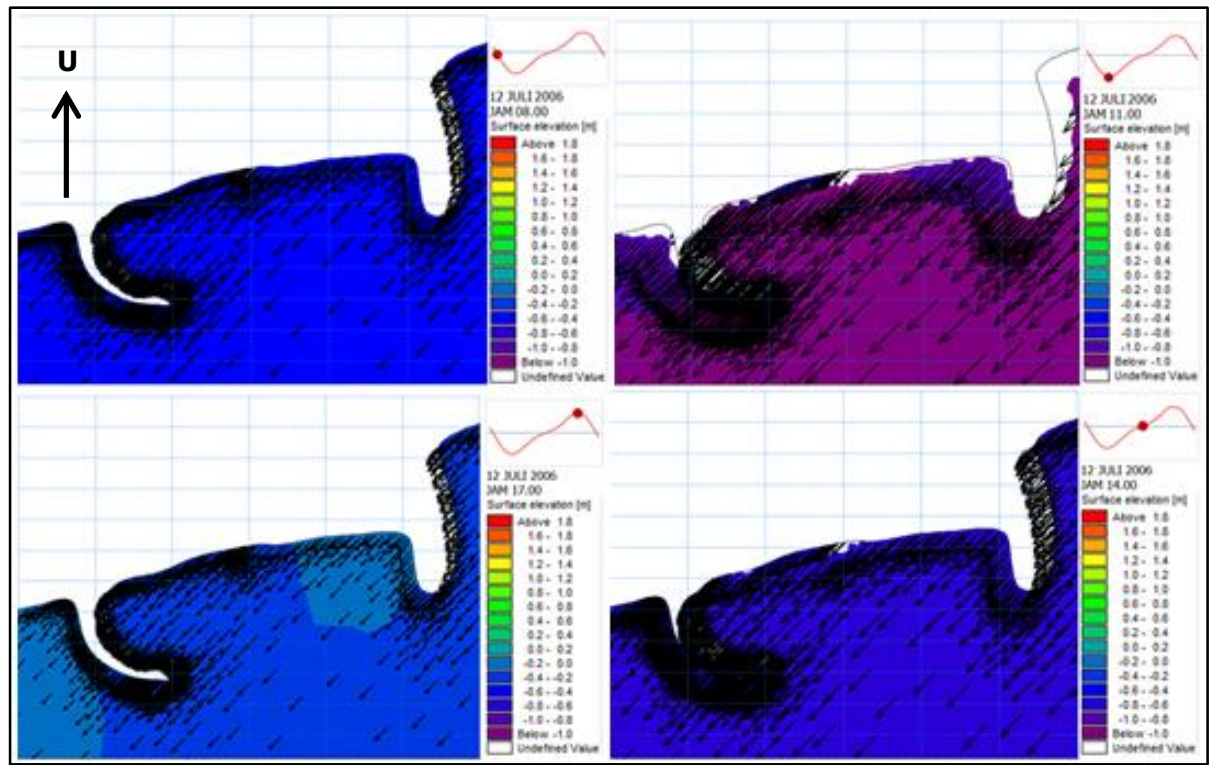

Gambar 5. Kondisi pasang perbani saat angin baratpada tanggal 12 Juli 2006

Gambar 5 menunjukan kondisi pasang perbanisaat angin barat yang masing-masing terjadi pada tanggal 12 Juli 2006 dengan beberapa kondisi, yaitu surut menuju pasang yang terjadi pada pukul 08.00, pasang tertinggi yang terjadi pada pukul 11.00 , pasang menuju surut yang terjadi pada pukul 14.00, dan surut terendah yang terjadi pada pukul 17.00, arus di sekitar pelabuhan ASDP Klungkung Bali bergerak dari arah timur laut ke arah barat daya. Elevasi muka air pada saat surut menuju pasang sebesar $-0,46 \mathrm{~m}$, pada saat pasang tertinggi sebesar $-1,02 \mathrm{~m}$, pada saat pasang menuju surut sebesar $-0,71 \mathrm{~m}$, dan pada saat surut terendah sebesar $-0,2 \mathrm{~m}$.

3. Kondisi pasang purnama pada saat angin timur (Desember s.d Februari)

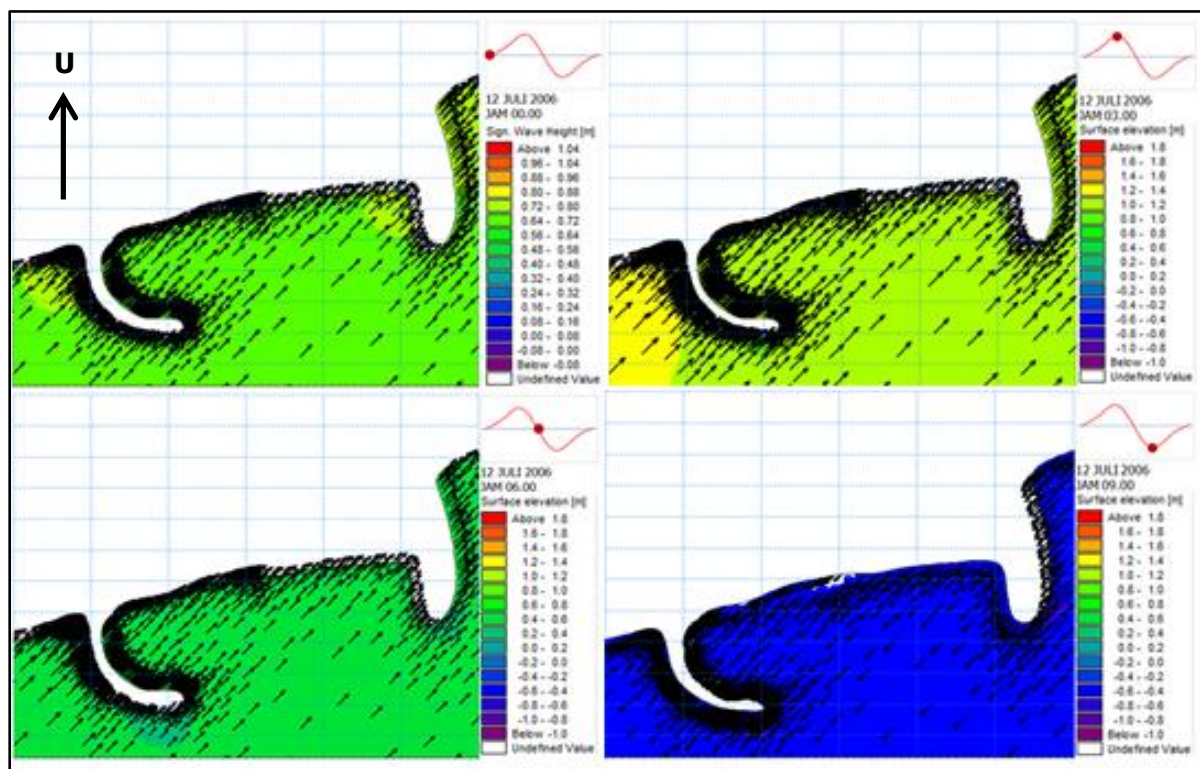

Gambar 6. Kondisi pasang purnama saat angin timurpada tanggal 12 Juli 2006

Gambar 6 menunjukan kondisi pasang purnama pada saat angin timur yang masing-masing terjadi pada tanggal 12 Juli 2006 dengan beberapa kondisi yaitu surut menuju pasang yang

RekaRacana: Jurnal Teknik Sipil - 101 
terjadi pada pukul 00.00 , pasang tertinggi yang terjadi pada pukul 03.00, pasang menuju surut yang terjadi pada pukul 06.00, dan surut terendah yang terjadi pada pukul 09.00, arus di sekitar pelabuhan ASDP Klungkung Bali bergerak dari arah barat daya ke arah timur laut . Elevasi muka air pada saat surut menuju pasang sebesar $0,76 \mathrm{~m}$, pada saat pasang tertinggi sebesar 0,94 $\mathrm{m}$, pada saat pasang menuju surut sebesar $0,23 \mathrm{~m}$, dan pada saat surut terendah sebesar $-0,75 \mathrm{~m}$.

4. Kondisi pasang perbani pada saat angin timur (Juni s.d Agustus)

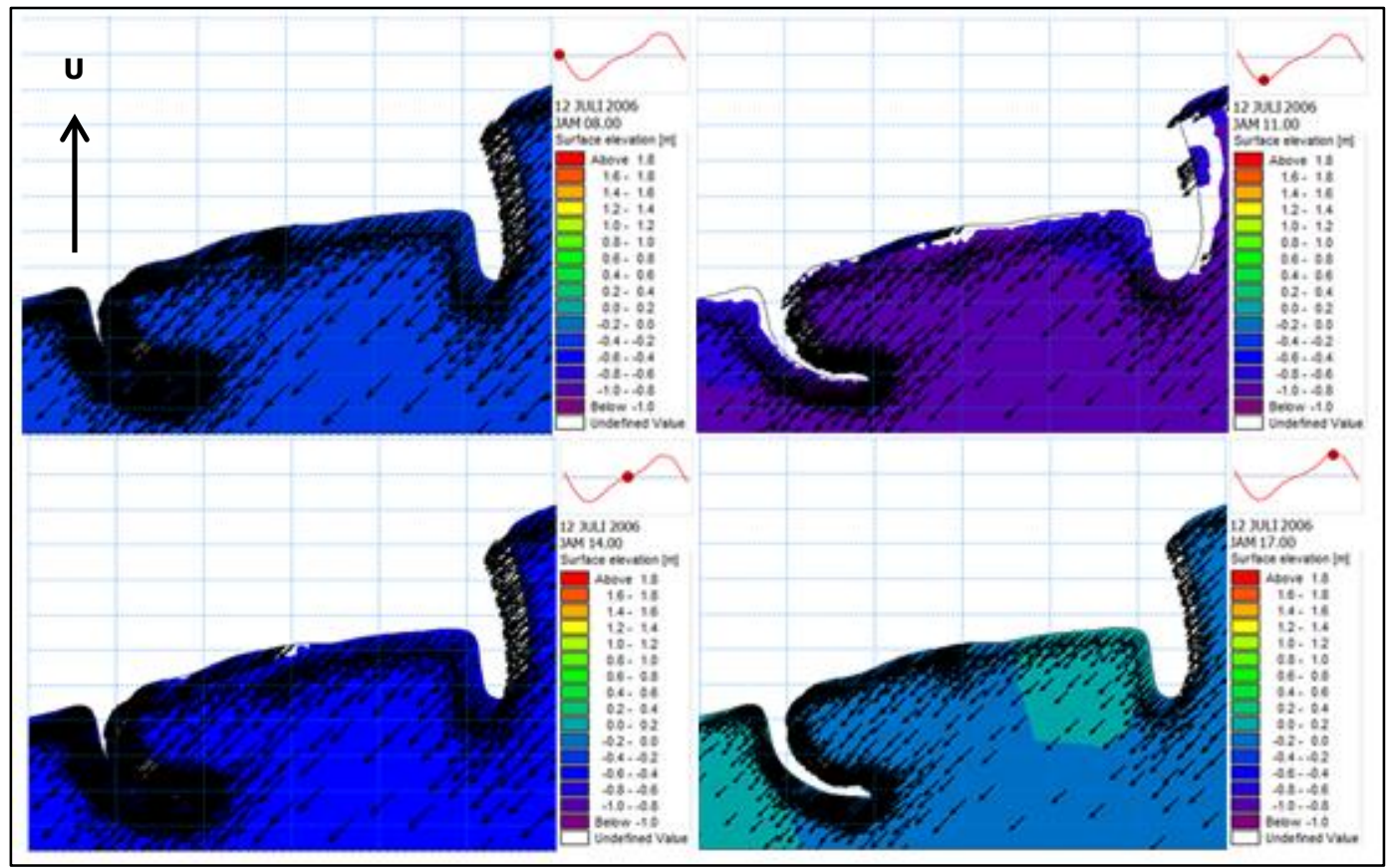

Gambar 7. Kondisi pasang perbani saat angin timurpada tanggal 12 Juli 2006

Gambar 7 menunjukan kondisi pasang perbani pada saat angin timur yang masing-masing terjadi pada tanggal 12 Juli 2006 dengan beberapa kondisi yaitu surut menuju pasang yang terjadi pada pukul 08.00, pasang tertinggi yang terjadi pada pukul 11.00, pasang menuju surut yang terjadi pada pukul 14.00, dan surut terendah yang terjadi pada pukul 17.00, arus di sekitar pelabuhan ASDP Klungkung Bali bergerak dari arah timur laut ke arah barat daya. Elevasi muka air pada saat surut menuju pasang sebesar $-0,46 \mathrm{~m}$, pada saat pasang tertinggi sebesar $-1,02 \mathrm{~m}$, pada saat pasang menuju surut sebesar $-0,71 \mathrm{~m}$, dan pada saat surut terendah sebesar $-0,20 \mathrm{~m}$.

\subsection{Hasil Analisis Transformasi Gelombang}

Berikut ini adalah hasil dari simulasi transformasi gelombang pada saat angin barat (Desember s.d Februari) dan angin timur (Juni s.d Agustus) dengan kondisi pasang purnama dan kondisi pasang perbani. 
1. Kondisi pasang purnama pada saat angin barat (Desember s.d Februari)

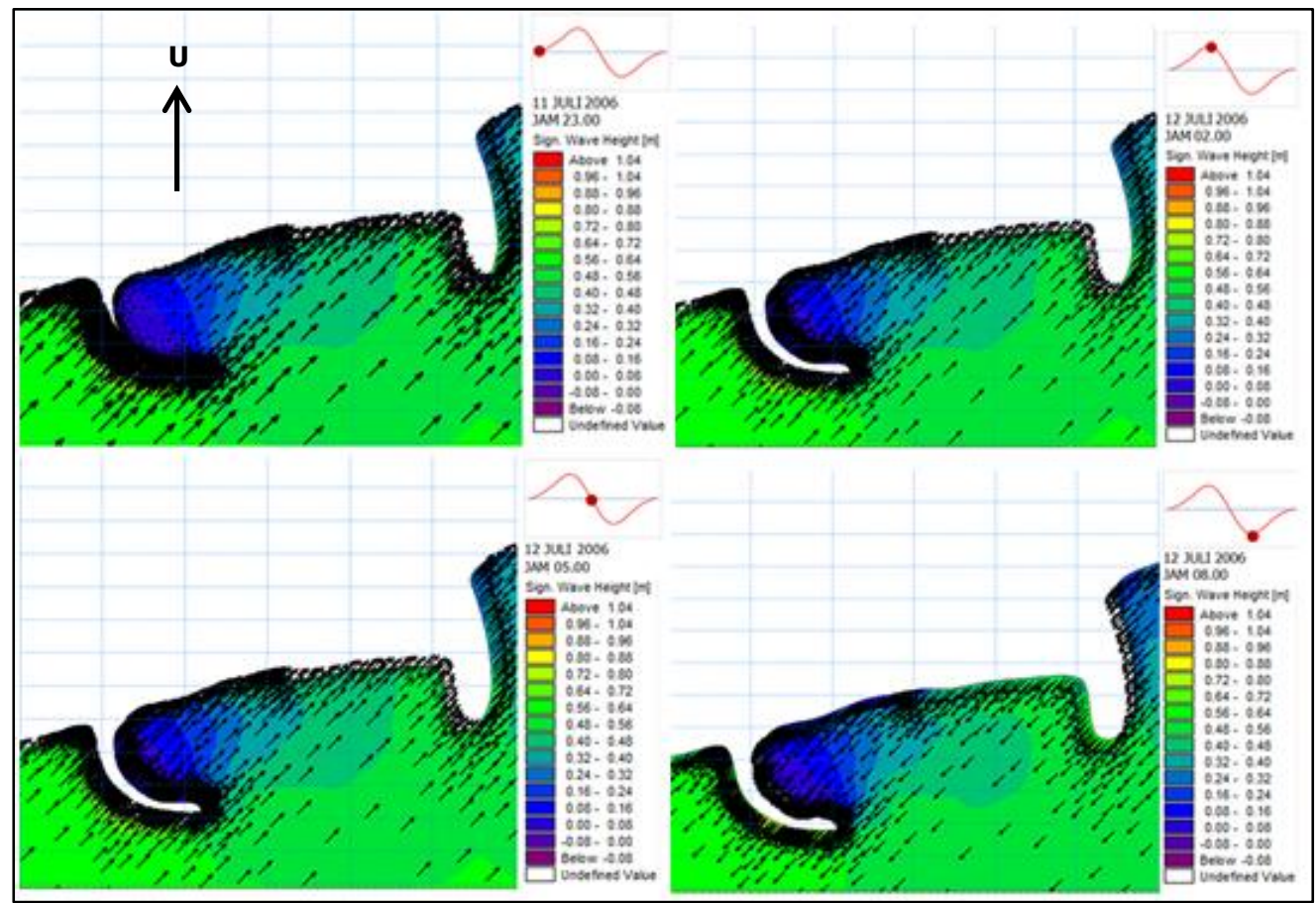

Gambar 8. Transformasi Gelombang pada pasang purnama saat angin barat pada tanggal 12 Juli 2006

2. Kondisi pasang perbani pada saat angin barat (Desember s.d Februari)

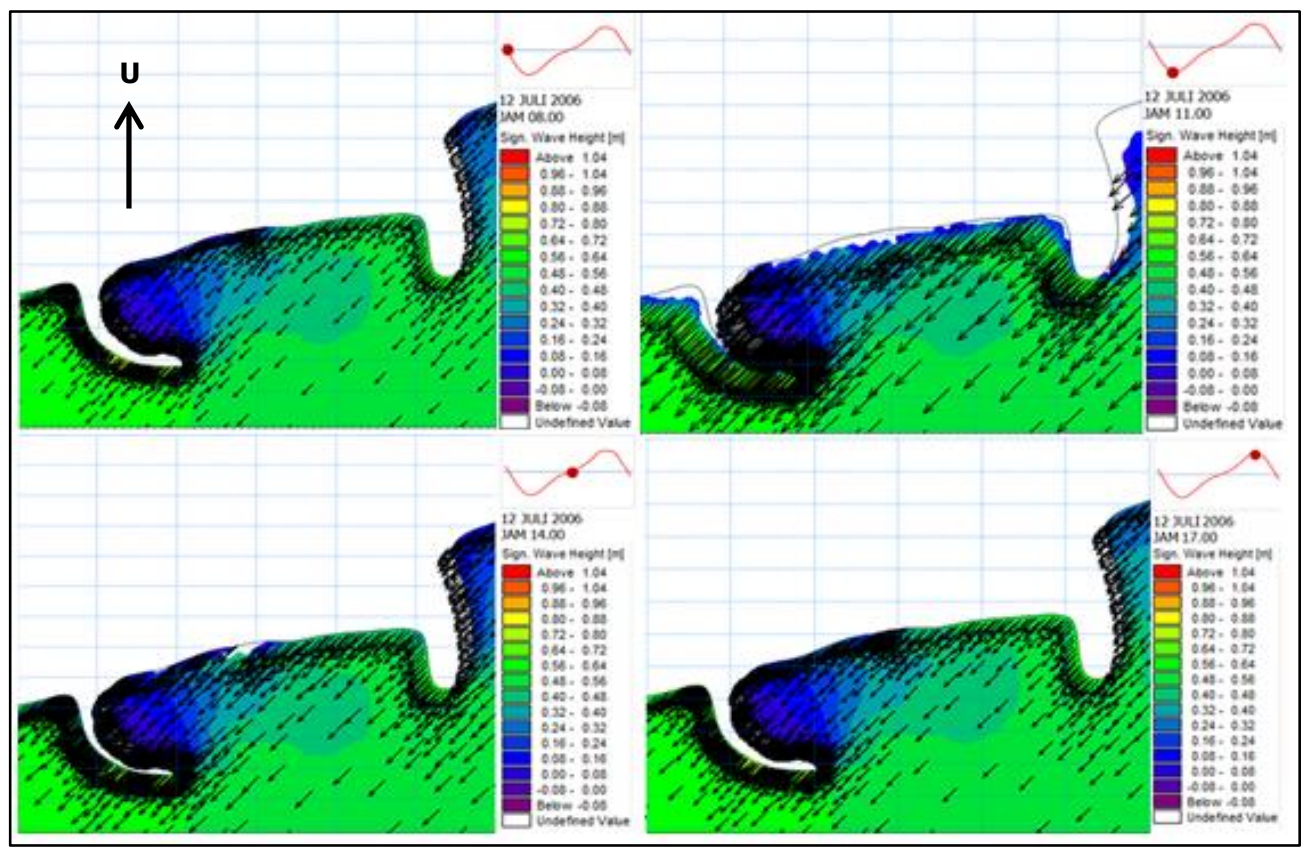

Gambar 9. Transformasi gelombang dengan kondisi pasang perbani saat angin barat pada tanggal 12 Juli 2006 
3. Kondisi pasang purnama pada saat angin timur (Juni s.d Agustus)

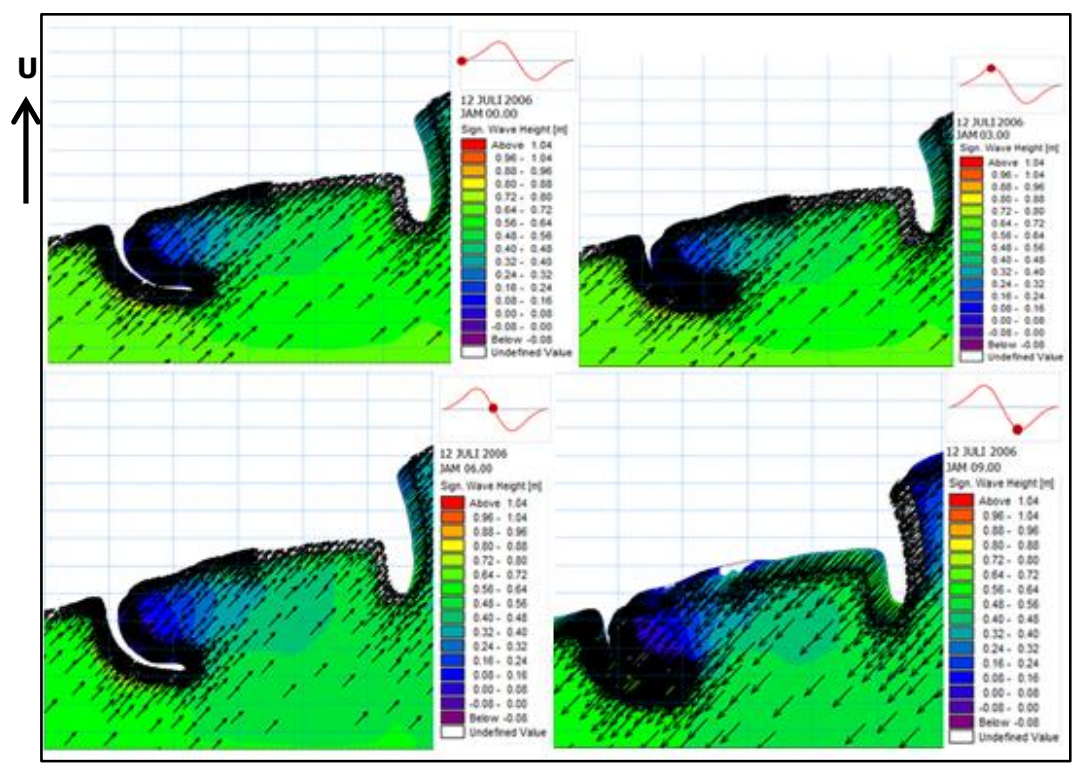

Gambar 10. Transformasi gelombang dengan kondisi pasang purnama saat angin timur pada tanggal 12 Juli 2006

4. Kondisi pasang perbani pada saat angin timur (Juni s.d Agustus)

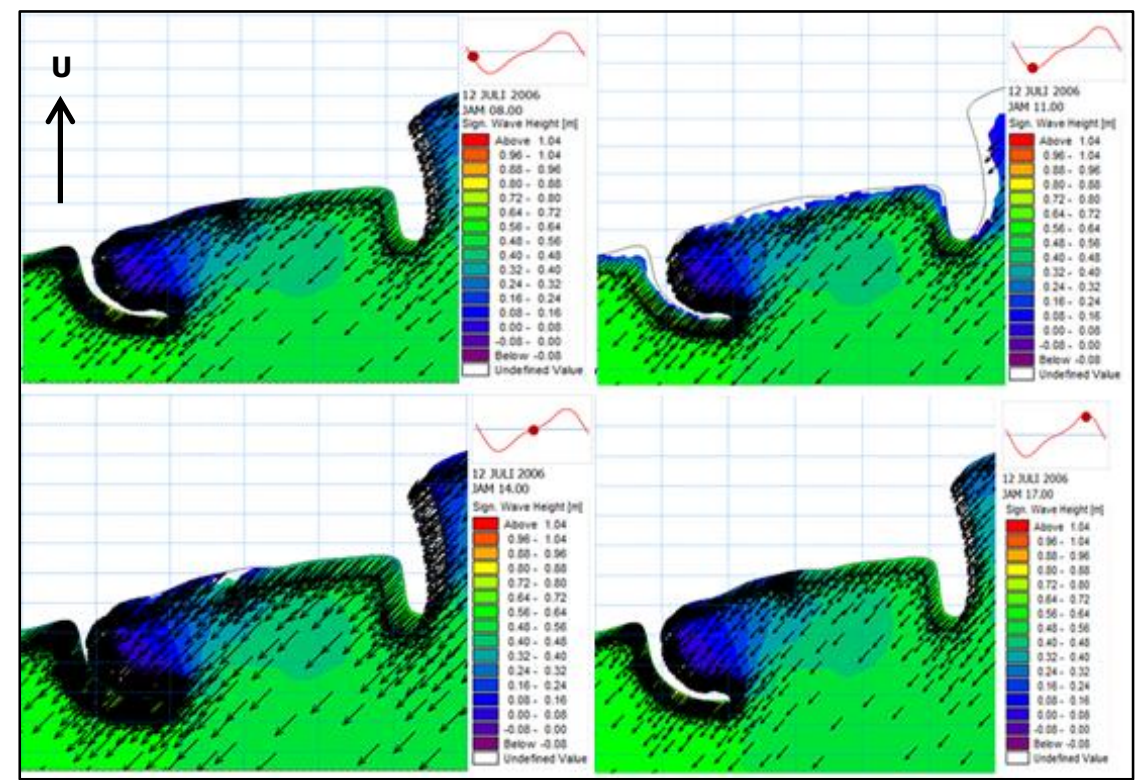

Gambar 11. Transformasi gelombang dengan kondisi pasang perbani saat angin timur pada tanggal 12 Juli 2006

Gambar 8 s.d Gambar 11 menunjukan transformasi gelombang yang terjadi di sekitar mulut kolam pelabuhan. Pada saat pasang purnama baik pada saat angin barat maupun angin timur arus bergerak dari arah barat daya ke arah timur laut yang memiliki tinggi gelombang sebesar 0,56 m-0,64 m, sedangkan pada kondisi pasang perbani baik saat angin barat maupun angin timur arus bergerak dari arah timur laut ke arah barat daya memiliki tinggi gelombang sebesar $0,48 \mathrm{~m}-0,56 \mathrm{~m}$. 


\section{Analisis Hidrodinamika dan Transformasi Gelombang bagi Re-design Breakwater \\ di Pelabuhan Klungkung Bali}

\section{KESIMPULAN}

\subsection{Kesimpulan}

1. Hasil dari validasi pasang surut pemodelan memiliki tingkat kesesuaian terhadap kondisi real atau kondisi di lapangan yang dilihat dari nilai RMSE (Root Mean Square Error) dan nilai korelasinnya. Pada penelitian ini digunakan Bed Resistencedengan manningsebesar $37 \mathrm{~m}^{1 / 3}$ dengan RMSE sebesar 0,2954 $\mathrm{m}$ atau sekitar $29 \mathrm{~cm}$ dan korelasi sebesar $81,4853 \%$.

2. Kondisi arus di perairan Pelabuhan Klungkung Bali pada saat pasang purnama, arus bergerak meninggalkan pelabuhan dari arah barat daya ke arah timur laut yang memiliki elevasi muka air tertinggi 0,9 m, sedangkan pada kondisi pasang perbani, arus bergerak meninggalkan pelabuhan dari arah timur laut ke arah barat daya yang memiliki elevasi muka air terendah $-1,02 \mathrm{~m}$.

3. Tinggi gelombang terbesar yang terjadi di sekitar mulut pelabuhan pada kondisi pasang purnama baik saat angin barat maupun angin timur memiliki tinggi gelombang sebesar $0,56 \mathrm{~m}-0,64 \mathrm{~m}$, sedangkan pada kondisi pasang perbani baik saat angin barat maupun angin timur memiliki tinggi gelombang sebesar 0,48 $\mathrm{m}-0,56 \mathrm{~m}$.

4. Dengan tinggi gelombang yang terjadi di sekitar mulut kolam pelabuhan saat pasang purnama sebesar 0,56 $\mathrm{m}-0,64 \mathrm{~m}$ dan saat pasang perbani sebesar 0,48 $\mathrm{m}-0,56 \mathrm{~m}$; tinggi gelombang tersebut melebihi dari syarat tinggi gelombang untuk pelabuhan yaitu 0,5 m; oleh karena itu Pelabuhan ASDP Klungkung membutuhkan re-design breakwater.

\section{UCAPAN TERIMA KASIH}

Ucapan terima kasih kepada PT LAPI ITB yang telah memberikan data-data yang dibutuhkan pada penelitian ini.

\section{DAFTAR RUJUKAN}

Fadli, M., Radjawane, I. dan Susanna. (2014). Pemodelan Hidrodinamika di Perairan Teluk Ambon. Oseanografi, ), $13-17$.

PT LAPI ITB. (2006). Laporan Akhir Pembangunan Pelabuhan ASDP Gunaksa. Bali

Triatmodjo, B. (2016). Teknik Pelabuhan. Yogyakarta: Beta Offset.

Triatmodjo, B. (2016). Teknik Pantai. Yogyakarta: Beta Offset. 